


\title{
SOME FACTORS INFLUENCING THE INCOME OF KALIGESING GOAT FARMERS IN BOROBUDUR SUBDISTRICT, MAGELANG REGENCY, CENTRAL JAVA, INDONESIA
}

\author{
A. Setiadi, S.I. Santoso, L.K. Nuswantara and Sunarso \\ Faculty of Animal Science and Agriculture, Diponegoro University, \\ Tembalang Campus, Semarang, 50275 - Indonesia \\ Corresponding email : agus_setiadi2006@yahoo.co.id \\ Received October 09, 2012; Accepted November 20, 2012
}

\begin{abstract}
ABSTRAK
Tujuan penelitian ini adalah untuk mengetahui jumlah pendapatan yang didapatkan oleh peternak dan mengetahui pengaruh beberapa faktor terhadap pendapatan peternak. Penelitian survei dilakukan pada 47 peternak kambing ras kaligesing di Desa Giripurno Kecamatan Borobudur, Kabupaten Magelang dengan cara interview dan observasi. Data sekunder dan primer diambil untuk menjawab penelitian. Karakteristik responden, total penerimaan, biaya produksi dan total pendapatan dicatat dan diamati selama 6 bulan. Statistika deskriptif dan one sample t-test digunakan untuk menganalisis data. Analisis jalur dengan TETRAD IV digunakan untuk menentukan model. Peternak kambing perah ratarata memelihara 10 ekor. Total penerimaan yang didapatkan perbulan sebesar Rp. 4.975.500, biaya yang dikeluarkan sebesar Rp. 1.865.200. Pendapatan yang didapatkan sebesar Rp. 3.110.300. Pendapatan yang didapatkan lebih besar dari Upah minimum regional (UMR). Harga susu dan kualitas susu mempengaruhi jumlah susu yang terjual. Jumlah susu yang terjual mempengaruhi pendapatan. Harga susu secara langsung mempengaruhi pendapatan namun kualitas susu tidak secara langsung mempengaruhi pendapatan. Perbaikan kualitas susu dengan manipulasi pakan perlu dilakukan.

Kata kunci: Kambing ras kaligesing, penerimaan, biaya, pendapatan, model
\end{abstract}

\begin{abstract}
The objectives of study to determine the income is obtained by Kaligesing goat farmer and to determine the effect of some factors on the income. Survey method was conducted in this study, 47 (forty seven) farmers in Giripurno village, Borobudur subdistrict, Magelang regency through interview and observation. Secondary and primary data were obtained to answer the objective. Respondent characteristic, total revenue, total cost production, and total income were observed for 6 months observation. Descriptive analysis and one sample t-test was used to analyze the data. Path analysis with TETRAD IV was used to determine the model. Dairy goat farmer in the study area rear goat were 10 heads on average. Total revenue obtained was IDR 4,975,500, Total cost spent was IDR 1,865,200, and Total income was IDR 3,110,300. Milk price and quality of the milk have influenced the number of milk sold. The number of milk sold has influenced the income significantly. Milk price has influenced directly to the income while quality of milk has not directly influenced the income of farmer. Hence, improvement of quality of goat milk through diet manipulation is needed.
\end{abstract}

Keywords: Kaligesing goat, revenue, cost, income, model

\section{INTRODUCTION}

Increasing of human population leads increasing the livestock product such as milk. At present, milk attracts the interest of consumer, because of its benefit. Milk goat is believed contain high n-3 PUFA. Some researchers (El Badry et al., 2007; Dommels et al., 2002; Tschakert, 2007; Givens et al., 2006) stated that n-3 PUFA have positive effect on human health. Dairy goat produce goat milk which many function for human (Pihlanto, 2006)), goat milk 
contain high CLA (Pihlanto, 2006), omega 3 (Pihlanto, 2006; Huffman et al., 2011). Milk believed can reduce the diabetes, cancer risks (Parodi, 1997). Thorsdottir et al. (2004) omega 3 contained in milk could prevent type 2 diabetes in men and coronary heart disease in woman. Kaligesing goat is an indigenous goat from Indonesia. Kaligesing goat was announced as local breed from Central Java by Ministry of Agriculture through Decisien Letter No. 2591/kpts/PD.400/7/2010 on 19 July 2010. This goat usually are raised in upland area such as Purworejo Regency and Magelang Regency. Contributions of Kaligesing rearing are 1) provide goat milk to the consumer, 2) provide additional income for the farmer's family, 3) reduce poverty in rural area. Budisatria and Udo (2012) stated there are some factors influencing the income of goat farmer in Central Java such as farmer behavior, capital, quality of goat and price. Improvement of those factors will influence the income of farmer. The income is obtained by farmer will influence the livelihood especially in rural area.

Intensification is one approach to increase the productivity and income of smallholder farmer (Moll et al., 2007; Udo et al., 2011). Kaligesing goat farming usually does by farmers in rural area as additional income beside their main income. Dairy goat farming contributes improve the livelihood especially for small scale farmers in rural area in Central Java. The cold weather of area support goat development. Central Java governments through department of animal husbandry and animal health always do some program to develop Kaligesing goat. The efforts show positive effect on increasing the number of Kaligesing goat in some area in Central Java. The price of milk and quality of milk are fluctuated; those factors are hypothesized influence income of the farmers. The objectives of study was to determine the income obtained by Kaligesing goat farmer and to determine the effect of some factors on the income.

\section{MATERIALS AND METHODS}

\section{Study Area}

The study was conducted in Giripurno village, Borobudur subdistrict, Magelang, Central Java province. Giripurno village is located in 700 $\mathrm{m}$ upper than sea. All of goat farmers in Giripurno are member of "Sari Makmur" group which won the $2^{\text {nd }}$ best farmer group in Indonesia. The village is very fit with Kaligesing goat requirement condition. The extension service and farming management were very good, so the success of the group could be followed by other group in Indonesia which interest to develop Kaligesing goat. The study was conducted for 6 months, start from April to August 2012. Forty seven farmers member of goat farmer group were chosen as respondents.

\section{Data Collection}

Survey method was used in the study. Secondary data and primary data were collected from depth interview with the goat farmers which helped questionnaire. Characteristics respondents such as age, educational background, number of family, number of goat, experience time were observed. Secondary data was obtained from the farmer recording. As the second best group performance in Indonesia, recording of farmer were completed. Secondary data are consisted of milk price, quality of milk recorded is based on milk fat and color, number of milk sold, monthly revenue, monthly cost of production and monthly income were computed to determine the income obtained by goat farmers.

\section{Statistical Analysis}

Descriptive analysis and one sample t-test were used in the study. Descriptive analyses were used to determine the characteristics of the respondents. One sample t-test was used to compare the income obtained by the goat farmers and minimum regional salary. SPSS version 16 was used to help the analysis. Tetrad 4 was used to determine the optimum economic model which influences the income of goat milk farmers. All of data were converted to score before analysis conducted (Ghozali, 2010).

Model of factors influencing the dairy goat farmer would follow:

$$
\mathrm{Y}=\mathrm{b}_{1} \mathrm{MP}+\mathrm{b}_{2} \mathrm{QM}+\mathrm{b}_{3} \mathrm{NMS}
$$

where:

$$
\begin{aligned}
& \mathrm{Y}=\text { income of dairy goat farmer (IDR) } \\
& \mathrm{MP}=\text { milk price (IDR) } \\
& \mathrm{QM}=\text { Quality of milk (score) } \\
& \mathrm{NMS}=\text { number of milk sold (liter) }
\end{aligned}
$$

$\mathrm{Y}$ is income of dairy goat farmers calculated by total revenue minus total cost, milk price (MP) is average price of milk a month, score was used to measure the quality of milk (QM) where 
1=bad; $2=$ fair and $3=$ good. Number of milk sold (NMS) was computed by total number sold a month.

\section{RESULTS AND DISCUSSION}

\section{Goat Farmers Characteristics}

Most of the farmers were 41-64 years old, showed that almost goat farmers still in productive age. Productive age of the farmers would support the goat development. Government of Magelang always support the farmers through provide some trainings such as artificial insemination, milk processing, and recording data. Finding the result showed $46.8 \%$ of the farmers were junior high schools passed, and just $2.1 \%$ graduated from university. Almost all farmers have experience more than 5 years. Usually farmers rear goat in high number (Table 1). The numbers of goats raised by farmers usually more than 10 because they found goat farming were profitable. At present the price of milk was IDR 15,000 to 20,000 per liter. Dairy goat business has been cultivated since early 2000 . The high price of milk, and high price of kid had attracted almost the farmers residence culture the goat. The area also is rich on leguminous which support goat business. Availability of feed is major factor attract people raise dairy goat in the area. Some training were done to increase skill and ability of the farmers.

\section{Cost of Production}

Cost of production consisted fix cost and variable cost. Feed cost was the highest cost spent by farmers. Total fix cost spent by farmers include goat depreciation, facility depreciation and cage depreciation. Variable spent by farmers include feed, salt, artificial insemination, labor, cage repair, plastic and other cost. Total cost spent by farmers per month was IDR 1,865,200. Feed cost was the main cost in goat rearing. Usually farmers fed goat with calliandra and other leguminous which grow well in surrounding area. Concentrates feeding were given to goat in small unit. Some farmers hire labor to looking for leguminous, labor cost spent by farmers was IDR 400,000 per month on average (Table 2).

\section{Revenue}

Revenue was obtained by farmers per month was IDR 4,975,500. Total revenue obtained from fresh goat milk sold per month was IDR $3,600,000$, the revenue obtained from kid goat
Table 1. Kaligesing Goat Farmers' Characteristics

\begin{tabular}{lrr}
\hline \multicolumn{1}{c}{ Identity } & $\begin{array}{c}\text { Number } \\
\text { (persons) }\end{array}$ & $(\%)$ \\
\hline Age( year) & 20 & 47.9 \\
$-\quad 15-40$ & 26 & 50.1 \\
$-\quad 41-64$ & 1 & 2.1 \\
$-\quad>64$ & & \\
Educational background & 21 & 44.7 \\
$-\quad$ Elementary & 22 & 46.8 \\
$-\quad$ Junior high school & 3 & 6.4 \\
$-\quad$ Senior high shool & 1 & 2.1 \\
$-\quad$ University & & \\
Main job & 35 & 74.5 \\
$-\quad$ Farmers & 12 & 25.5 \\
$-\quad$ Non farmers & & \\
Family number & 20 & 47.9 \\
$-\quad 1-4$ & 26 & 50.1 \\
$-\quad$ 5-7 & 1 & 2.1 \\
$-\quad 7-9$ & & \\
Farmers experience & 21 & 4.3 \\
$-\quad 1-10$ & 20 & 68.1 \\
$-\quad 11-20$ & 6 & 27.6 \\
$-\quad 21-30$ & & \\
Goat numbers & 41 & 87.2 \\
$-\quad 10-24$ & 5 & 10.7 \\
$-\quad 25-44$ & 1 & 2.1 \\
\hline$\quad 45-61$ & & \\
\hline
\end{tabular}

sold was IDR 160,000, the revenue obtained from selling feces was IDR 15,500, and additional value from goat reared was IDR 1,200,000. Based on observation, farmers very satisfy raised goat (Table 3).

As shown in Table 3. Total revenue dominant came from selling fresh goat milk. During the study the price of goat milk was high. The condition lead the revenue was high too.

\section{Income}

Income was computed by subtracting revenue was obtained with cost of production spent by farmers. The income obtained from raising goat was IDR 3,110,300 (Table4). The condition result was in good livelihood in the area.

As shown in Table 5. the income was obtained by farmers was higher than minimum regional salary of Magelang district, the condition supported by some research was done by some 
Table 2. Cost of Production Goat Raising in Study Area

\begin{tabular}{lr}
\hline \multicolumn{1}{c}{ Cost } & $\begin{array}{c}\text { Average (IDR/10 } \\
\text { goats/month) }\end{array}$ \\
\hline Fix cost & \\
Goat depreciation & 459,000 \\
Facility depreciation & 5,600 \\
Cage depreciation & 10,000 \\
Variable cost & \\
Feed & 923,500 \\
Salt & 2,600 \\
Medicine & 4,000 \\
Artificial Insemination & 5,000 \\
Labor & 400,000 \\
Cage Repair & 20,000 \\
Plastic & 23,000 \\
Other cost & 12,500 \\
Total & $1,865,200$ \\
\hline
\end{tabular}

Currency 1USD \$ = IDR 9,300

Table 3. Revenue Obtained by Goat Farmers

\begin{tabular}{lc}
\hline \multicolumn{1}{c}{ Item } & $\begin{array}{c}\text { Average } \\
\text { (IDR/10 goats/month) }\end{array}$ \\
\hline Fresh goat milk sold & $3,600,000$ \\
Kid goat sold & 160,000 \\
Feces sold & 15,500 \\
Goat additional value & $1,200,000$ \\
added & \\
Total & $4,975,500$ \\
\hline
\end{tabular}

researchers (Lindenlauf et al., 2010; Hansson and Ferguson, 2011). They conclude that small ruminant research could improve the livelihood in rural area. Improvement of market, feed availability and price of the product would improve the goat business. The goat rearing in order to improve livelihood in rural area could be implemented. Strategy to develop goat such as provide better feed, better milk price is needed to improve the goat development. The high income was obtained by farmers generate from Kaligesing goat rearing showed Kaligesing goat are potential to develop in Magelang subdistrict.
Table 4. Average Income Obtained by Goat Farmers

\begin{tabular}{lc}
\hline \multicolumn{1}{c}{ Item } & $\begin{array}{c}\text { Average } \\
\text { (IDR/10 goats/month) }\end{array}$ \\
\hline Revenue & $4,975,500$ \\
Cost of Production & $1,865,200$ \\
Income & $3,110,300$ \\
\hline
\end{tabular}

Table 5. One Sample t-test Comparison between Income and Minimum Regional Salary

\begin{tabular}{lc}
\hline \multicolumn{1}{c}{ Item } & $\begin{array}{c}\text { Average } \\
\text { (IDR/10 goats/month) }\end{array}$ \\
\hline Income & $3,110,300$ \\
$\begin{array}{l}\text { Minimum regional } \\
\text { salary }\end{array}$ & 960,000 \\
\hline
\end{tabular}

\section{Factors Influencing the Income}

As shown in Figure 1, the model was fit. Chi square was small, degree of freedom was 1 and probability was 0.65 . Milk price influence number of milk sold significantly $(\mathrm{P}<0.05)$. Result showed that the increasing of milk price also would increase the income. If milk price increase by IDR 1 hence income would increase by IDR 0.18 when the other factors constant (Table 6). Quality of milk significantly influence the number milk sold. The increasing quality of milk by 1 score would increase the number of milk sold by 0.04 liter. Number of milk sold influenced significantly the income. The number of milk sold increased by 1 liter enhances the income by IDR 0.37 when the other factors constant. Quality of milk was not significantly $(\mathrm{P}>0.05)$ influenced the income. Coefficient obtained in path analisis was -0.07 , it means that quality of goat milk need to improve. Result of study showed the quality of milk was fair category. Improvement of milk quality will increase milk sold and finally will increase the income. Further research on improvement of milk quality through diet manipulation is needed. The result was supported by Panin and Mahabile (1997) which stated the increasing of milk quality will increase the selling of number of product. Milk price would influence the profitability of goat milk hence would increase the welfare of farmers in rural area.

Based on path analysis, to increase the 


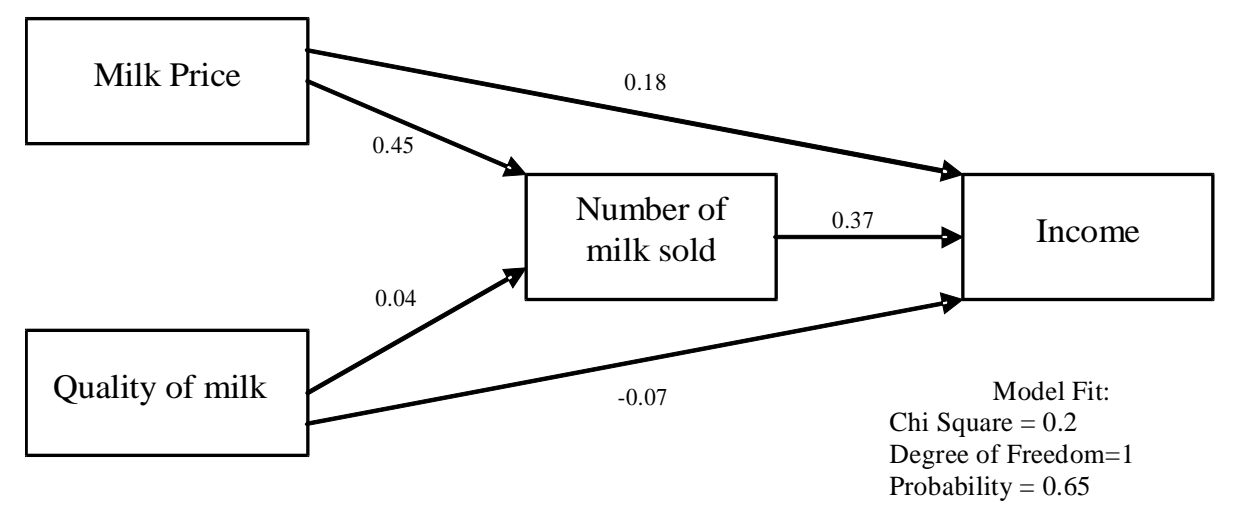

Figure 1. Model to Increase the Goat Farmer Income

income of dairy goat farmer could be conducted through improvement of goat milk price. Milk quality could be improved by diet manipulation. Further research is needed through goat feeding trial on milk quality. Improvement of milk quality would increase the milk price and finally would increase the income..

\section{CONCLUSION}

Based on the research, goat farming was able to generate additional income for farmer. The income obtained was higher than the minimum regional salary in Magelang regency. Milk price and quality of milk sold have influenced the number of milk sold. Milk price significantly influenced the income, while quality of milk sold was not significantly influenced the income. Number of milk sold influenced significantly the income. Further research on effect of alternative feed resources is needed on goat milk quality to enhance the number milk sold. Production of high quality of goat milk would increase the price and finally would increase the farmer's income.

\section{ACKNOWLEDGMENTS}

The authors thank to Diponegoro University which fund the research through Hibah Kompetitif dana PNBP UNDIP No contract 259.4/UN7.5/PG/2012, and farmers in Giripurno village who very cooperative to fill the questionnaire.

\section{REFERENCES}

Budisatria, I.G.S and. H.M.J. Udo. 2012. Goat based aid programme in Central Java: an effective for the poor and vulnerable? Small
Ruminant Research. 2:12-28

Huffman, S.L., R.K. Harika., A. Eilander., and S.J.M. Osendarp. Essential fats: how do they affect growth and developments of infants and young children in developing countries? A literature review. Maternal and Child Nutrition. 7 (Suppl.3) pp 44-65

Ghozali, I. 2010. Structural Equation Modeling: Mencari Hubungan Kausalitas Antar Variabel Pendekatan Induktif Dengan Program TETRAD IV. Badan Penerbit Universitas Diponegoro.

Gursoy, O. 2006. Economics and profitability of sheep and goat production in Turkey under new support regimes and market conditions. Small Ruminant Research 62:181-191

Hansson, H, and R. Ferguson. 2011. Factors influencing the strategic decision to further develop dairy production-A study of farmers in central Sweden. Livestock Science. 135:110-123

Moll, H.A.J., S.J. Stall., and M.N.M. Ibrahim. 2007. Smallholder dairy production and markets: A comparison of production systems in Zambia, Kenya and Sri Lanka. Agricultural systems. 94:593-603

Muller-Lindenlauf, M., C. Deittert., and U. Kopke. 2010. Assesment of environemntal effects, animal welfare and milk quality among organic dairy farms. Livestock Science.128:140-148

Panin, A., and M. Mahabile. 1997. Profitability and household income contribution of small ruminants to small-scale farmers in Botswana. Small Ruminant Research. 25:915

Parodi, P.W. 1997. Cows'milk fat components as potential anticarcinogenic agents. J. Nutr. 127: $1055-1060$ 
Pihlanto, A. 2006. Antioxidative peptides derived from milk proteins. International Dairy Journal. 16:1306-1314

Thorsdottir, I., J. Hill, and A.Ramel. 2004. Omega 3 fatty acid supply from milk associates with lower type 2 diabetes in men and coronary heart disease in women. Preventive Medicine. 39:630-634

Tschakert, P. 2007. Environmental services and poverty reduction: Options for smallholders in the Sahel. Agricultural Systems. 94:75-86

Udo, H.M.J., H.A. Aklilu., L.T. Phong., R.H. Bosma., I.G.S. Budisatria., B.R. Patil., T. Samdup and B.O. Bepe. 2011. Impact of intensification of different types of livestock production in smallholder crop-livestock systems. Livestock Science.139:22-29 